As a whole, in morphology, appearance of colonies and growth, the organism resembles that described by Flexner and Noguchi ${ }^{2}$ in poliomyelitis. It differs in results obtained with animals and particularly in the susceptibility of rabbits to this organism.

Up to the present time, the filtrable organism has been carried to the twelfth generation. It has been recovered from the brains of rabbits and monkeys injected with filtrates of human nasopharyngeal mucous membrane and of brains of inoculated animals. Monkeys and rabbits injected with the later generations (seventh to eleventh) of the organism, originally obtained from human mucous membrane and not previously passed through animals, have succumbed with typical symptoms. Necropsy findings and microscopic pictures are characteristic of those found in the human being. The organism was recovered from the brains, and, in a few instances, from the mucous membranes of the nasopharynx of these animals. Use of the later generations excludes the possibility of the transmission of sufficient original virus to produce any such results.

The organism was recovered from 50 per cent. glycerinated filtrate of human nasopharyngeal mucous membrane kept on ice for four months. The organism remains viable and virulent in cultures for a period of at least six weeks.

\section{OPEN AIR CLASSES *}

\section{LEOPOLD MARCUS, M.D.}

Supervising Inspector of Open Air Classes, Bureau of Child Hygiene, Department of Health

NEW YORK

The Bureau of Child Hygiene of the department of health of New York City conducts only activities of preventive medicine. These activities cover a period of the child's life from the prenatal state until the completion of the elementary school. The activities are controlled by definite divisions of the bureau to cover various periods of life, as well as special activities. The division of baby welfare supervises the prenatal work and care of the infant from birth until the second year is reached. The division of midwives and foundlings issues permits to midwives and supervises their methods in carrying on their practice. It also issues permits for the privilege of keeping foundlings, and supervises the care they receive. The division of school medical inspection conducts a progressive campaign of preventive medicine throughout the year, both in the schools and in the homes of the pupils. The division of employment certificates issues certificates only to schoolchildren of correct age who are in physical condition to work. There is a division of eye clinics and a division of dental clinics which conduct their special branches of medicine exclusively for the benefit of schoolchildren.

The preschool age of the child, that is, from the second year until the child's entrance into school, is not systematically supervised. Some pioneer work has been done by our bureau, and the necessity and value of it have been conclusively proved. This period of the child's life can no longer be neglected, and one of the next steps in public health and preventive medicine will be the giving of more attention to it.

* Read before the Section on Preventive Medicine and Public Health at the Seventieth Annual Session of the American Medical Association, Atlantic City, N. J., June, 1919.
One of the activities of the division of school medical inspection is the medical supervision of the open air classes of the public schools. The pedagogic work of these classes is conducted entirely by the board of education.

The classes were organized to provide special opportunities for the physically subnormal pupils, after an experiment had been conducted in one class to ascertain the value of such organization. The results have been so gratifying that there are now 110 open air classes. The classes are at present located on the roofs of the school buildings, roofs of auditoriums, in public parks and in the school buildings.

Our experience has proved that in a large city these classes are best placed in the school building, in a classroom properly located and with the required structural changes. Besides, it is difficult to protect them from the rain, snow, direct sunlight and dust. Roofs require the climbing of too many stairs. Locations in the parks would be ideal were it not for the expense of the structures required. Besides, in our city, the parks available are so inadequate that only a small number of classes can be located in them. When the original school building is being constructed, very little additional cost is added by providing one or more open air classrooms. The board of education now provides at least one open air classroom in every new school building.

At present the following types of children are admitted to the open air classes :

1. Children exposed to tuberculosis at home, or in whose family there has been a recent death from this disease.

2. Children who have had tuberculosis which is now arrested or cured.

3. Children suffering from malnutrition.

4. Children who become tired easily or show languor or fatigue before the end of the day, and on this account are unable to carry on their class work.

5. Children suffering from nervous diseases except chórea.

6. Children who frequently are absent because of colds, bronchitis, etc.

7. Children suffering from cardiac disease, who are recommended by the private physician as pupils who ought to be put in these classes.

The classification provides for the tuberculous, pretuberculous and physically subnormal children who may be benefited by becoming pupils in one of these classes.

The regular equipment for open air classes consists of individual school study chairs, cots and sleeping bags. The study chairs are easily movable, and groups of any of the children can be formed for the convenience of the teacher. The children use their sleeping bags when sitting in their study chairs or lying on their cots.

The important factors in the success of this work are fresh cool air, light, food, correction of physical defects that retard growth and development, and proper hygienic living conditions. These are all provided for during the school session. But it must be borne in mind that the children are in school only five hours a day on school days and that we have about 190 school days a year.

During the school hours, the children are completely under control and receive the care they require. The classrooms have ample light and air, as they are always located where these can be provided. Our choice is always a southern and eastern exposure when these are procurable. We have found that the cold air 
is a decided advantage and that no temperature is too low, provided the children are properly protected by their clothing and their sleeping bags. The greatest increase in weight is always made during the colder weather. With the first return of warm weather, the increase of weight is retarded. This is, to a great extent, because of the influence of the temperature on the appetites of these children. Their appetites are always better in colder weather.

Food is one of the essentials for children of these types, and we have found that three meals a day are not sufficient to assist them to a normal average weight. Extra feeding is always provided between breakfast and lunch and, as far as possible, between lunch and supper. This extra food is absolutely required by the children during the colder weather, and they all anxiously await it. Milk and bread and butter are the best foods for them; but our funds, which all come from private sources, have been limited, and for the past year and a half we have had to rely on cereals and milk. All classrooms located in new buildings, as well as many in the old ones, have a separate kitchen in which to prepare the food.

The children whose growth and development has been retarded because of physical defects, such as adenoids, hypertrophied tonsils and carious teeth, respond very quickly after their defects are properly remedied. Though they would in most cases improve in regular classes after correction of their defects, the improvement is more rapid when they have the advantages provided in the open air classes. Nearly all of these children having physical defects improve while in these classes, but return to their previous condition rapidly if sent back to a regular class.

TABLE 1.-DAILY ROUTINE OF AN OPEN AIR CLASS

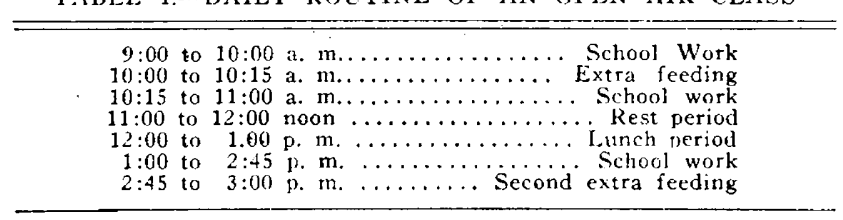

In school, the children have frequent short recesses for recreation. They have a rest period of one hour before lunch, during which time all children lie on their cots. Some learn to sleep during this period, but many merely rest. The daily routine followed in an open air class (Table 1) divides the day into three periods: two hours for school work, two hours for rest and lunch and, again, two hours for school work. We have the long rest period before lunch, as we have found that if we stop the school work after two hours to give the children a long rest, they do not become overfatigued. They recuperate rapidly, and by lunch time are fully back to their normal condition; and, furthermore, not being fatigued, they have good appetites, and derive the benefits which accrue from eating large meals.

Classes that are located on the upper floors have a rest period from 1 to $1: 10 \mathrm{p}$. $\mathrm{m}$. also. The time is deducted from the morning period of rest, and is given to afford the children a short rest after climbing so many stairs.

Parents are instructed to have their children rest at home before supper, and they are also urged to continue the morning extra feeding and to see that the children rest during the usual time on those days when the school is not in session.
The most difficult problem we have to contend with in a large city is that of the hygienic conditions at home. They entail a great deal of social service work, which, however, our teachers and nurses willingly do. This work may appear foreign to the subject, but it cannot be neglected, for all the results gained in school will avail nothing unless the home conditions are properly corrected.

From our present experience, I believe that the factors already enumerated are the important ones, and none of them can be slighted if success is to be our goal.

\section{MEDICAL ATTENTION AND TEACIIERS}

The classes are visited daily by the school nurses of the health department. Their duties are definitely defined, and they work in cooperation with the medical inspectors and the teachers. The medical inspectors of the health department have full medical charge of these classes. They admit and discharge pupils, make regular systematic physical examinations of all pupils, and repeat the examination in any individual case as often as the child may require it. All the work of the nurses and inspectors in the classes and in the homes of the pupils is recorded on individual record cards for each pupil.

The medical inspectors decide the extent of physical exercise in which each pupil is permitted to participate. The department of physical training of the board of education supervises the exercises and play, and regulates them for each pupil according to the limitations ordered by the medical inspectors.

The scholastic work is entirely under the supervision of the board of education. The classes are limited to a registration of twenty-five pupils. As these pupils are usually in various grades, the group method of teaching is used. (Only essential subjects can be taught.

Teachers of open air classes are specialists, and only those filling the required qualifications are selected. The qualifications considered essential are: good health; even temperament; capacity for doing a large amount of school work well, as a number of grades must be taught; physical ability to make home visits; tact in handling both children and parents; willingness to do social service, and a desire to study the problems of this work in the class by reading and taking an appropriate study course.

A poor teacher, or one not physically strong, is a great handicap to an open air class, as the success of the work rests to a great extent on her.

RECORD OF PUIILS

Children who are transferred from the open air class to a regular class are seen at least once a month by the

TABLE 2.-CASES DISCHARGED FROM OPEN AIR CLASSES

\begin{tabular}{lccccc}
\hline \hline $\begin{array}{l}\text { Gained } \\
\text { Weight }\end{array}$ & Remained & Scholarship & & \\
319 & Same & Lost & Improved & Same & Worse \\
& 43 & 5 & 70 & 292 & 5 \\
\hline
\end{tabular}

nurse, who keeps a record of their condition, weight and scholastic standing. Of 506 children transferred, 367 were followed up, with the results observed in Table 2.

The effects on all pupils in the open air classes are shown in Table 3.

Those children who failed to gain in weight were suffering from physical defects of such marked char- 
acter that it is most reasonable to attribute their failure to gain to this known cause. The children who failed at least to maintain their regular scholastic standings are mental defectives, as their previous records show. These children ought not be placed in open air classes, as it is impossible to give them there the attention they demand. TABLE 3.-PROGRESS OF ALL PUPILS IN OPEN AIR

\begin{tabular}{cccccc}
\hline Gained More & Average & \multicolumn{2}{c}{ Less Than Scholarship } & & \\
Than Average & Gain & Average & Improved & Same & Worse \\
2,131 & 796 & 79 & 718 & 2,198 & 90
\end{tabular}

We have one open air class with pupils of the usual average physical condition. This class has been conducted by the same teacher for five years, and the pupils, all boys, are in one of the grades of the last two years of the elementary school. It is a regular class placed in an open air classroom. All the work of their grade is covered. They have no cots, and only short recesses without a rest period. They do receive the morning extra feeding. They do their drawing and shop work in a regular classroom during the cold weather. All the rest of their school work is done in their own room, which is always at the temperature of the outside air. This class has a registration of fortyfive pupils.

The observations made during the past five years, of ten separate classes, fully demonstrate many facts which are all proved by the records of the various classes. These results can be best summed up by drawing a comparison between the scholastic and physical records maintained in the open air classrooms and those in the regular classrooms of the same grades, as shown in Table 4.

TABLE 4.-STANDARDS
IN OPEN AIR CLASS ROOM AS
COMPARE WITH THOSE IN REGULAR CLASS ROOMS

\begin{tabular}{|c|c|c|}
\hline & Pupils & Teacher \\
\hline $\begin{array}{c}\text { Scholastic } \\
\text { Record }\end{array}$ & $\begin{array}{l}\text { Work: Full work or more. } \\
\text { Penmanship: Satisfactory. } \\
\text { Application: Better ..... } \\
\text { Progress: More rapid.... } \\
\text { Effort: Increased . . . . } \\
\text { Written work: Not handi- } \\
\text { capped. } \\
\text { Absences: Decreased .... } \\
\text { Sickness: Lessened .... } \\
\text { Promotions: Higher Aver- } \\
\text { age. } \\
\text { Less home work required. }\end{array}$ & $\begin{array}{l}\text { Easier to get results. } \\
\text { Less mental tax. } \\
\text { Can cover more than pre. } \\
\text { scribed course in as. } \\
\text { signed time. }\end{array}$ \\
\hline $\begin{array}{l}\text { Physical } \\
\text { Record }\end{array}$ & $\begin{array}{l}\text { More active and respon- } \\
\text { sive to work. } \\
\text { Display ability and will- } \\
\text { ingness to do more. } \\
\text { Show an increase in } \\
\text { weight more than the } \\
\text { average gain. } \\
\text { Show no fatigue from } \\
\text { scholastic work. }\end{array}$ & $\begin{array}{l}\text { Physical condition easily } \\
\text { maintained. } \\
\text { No loss of weight. } \\
\text { Absences less. } \\
\text { Daily fatigue not appreci. } \\
\text { able. }\end{array}$ \\
\hline
\end{tabular}

The improvement in the physically subnormal children in open air classes over those in regular classes is now a well established fact, and the only handicap is the number of such classes necessary. A great many more are required than are now provided for; but we are unable to use many more classrooms for only twenty-five pupils while there are so many part time classes in existence in our city. The open air classroom is still an experiment and must remain so until we have ample school buildings to permit the organization of as many open air classes as are required.

\section{OPEN AIR CLASS WORK FOR ALL PUPILS}

Our experiment with a regular class in an open air classroom opens up another field, however; now that there is such an active campaign to improve the physical condition of the nation, there appears to us no better way to effect the improvement than by extending the use of the open air classroom to every schoolchild. If the routine can do so much for the subnormal, is it not natural to expect at least as much for the average child? To change to open air class work would naturally entail a marked reform in our school buildings and could not be immediately put into operation. But we do look forward to the time when we will strive to raise a hardy race and not hothouse plants. A building properly constructed would require no heat in any other classrooms than those used for manual work, such as shop work, designing, cooking, etc., provided the children were properly equipped to be protected from low temperatures. Such a step would be a great progress in preventive medicine. Any one who has the opportunity of visiting a regular and an open air classroom during the winter can readily decide for himself which one is conducive to growth, development and health. We look forward to the time, not far off, when we shall be able to conduct an entire school of normal children as an open air class school.

\section{RESULTS}

From the observations made so far, these results of open air class work can be enumerated:

1. Physically subnormal children improve in their mental and physical condition.

2. Their nutrition and weight improve.

3. The gain, in most instances, will be permanent.

4. In arrested cases of tuberculosis there are no relapses.

5. The nervous system is restored to a normal condition.

6. In cardiac cases pupils kept under proper medical supervision improve markedly.

7. The capacity for doing work is increased and brought to at least a normal average.

8. Absence from school on account of illness is greatly reduced.

9. A proper diet is followed, and the food is properly prepared.

10. Good habits are established.

11. Hygienic rules are lived up to.

12. Children learn how to do the right things at the right time.

It is our firm belief that average children will give even better results if afforded the same opportunities. ${ }^{1}$

\section{ABSTRACT OF DISCUSSION}

Miss Annie Morrison, Grand Rapids, Mich.: I find that the dangers with the ungraded rooms are often greater than the dangers with the normal children in the realm of education. As to the personal guidance, when the abnormal children reach the age at which they go to work, between 14 and 16, is there any vocational guidance in New York for these children? We find that when the child in the ungraded room of the open air school leaves the school and goes to work, it ought to be guided, because it is not fitted bodily for the average work which is required of a physically fit laboring man or woman. Then, again, is any study given to the kind of work that the child afflicted with tuberculosis shouid be engaged in after the school age.

1. A detailed account of the method of conducting open air classes of New York City appeared in the Monthly Bulletin of the Department of Health, City of New York, October, 1918. 